\title{
Evolution of Cloacal Bacteria and Fungi in Brahma Chickens (Gallus gallus domesticus) Fed with Chromolaena odorata Supplement
}

\author{
Pierrette Ngo Bahebeck ${ }^{1,2}$, Chouegouong Tuedom Mireille ${ }^{1}$, Nguemmogue Ghislaine ${ }^{1}$, \\ Ghomsi Magne Sandra Olivia ${ }^{1}$, Tamsa Arfao Antoine ${ }^{2}$, Mama Iréne ${ }^{1}$, \\ Enamou Mbanga Gatien ${ }^{1}$, Sulem Yong Nina Nindum ${ }^{1,2}$ and Etchu Kingsley Agbor ${ }^{1 *}$ \\ ${ }^{1}$ Institute of Agricultural Research for Development (IRAD), Yaoundé, P.O. BOX 2123 \\ ${ }^{2}$ Laboratory of Hydrobiology and Environment, Faculty of Science, University of Yaoundé I, \\ Yaoundé, P.O Box 812 Cameroon \\ *Corresponding author
}

\section{A B S T R A C T}

A study was conducted to evaluate the evolution of cloacal bacteria and fungi in Brahma (Gallus gallus domesticus) chickens fed with a Chromolaena odorata supplement. A total of 180 cloacal samples were collected over a 10 weeks period from August to October 2020. Three feed rations $\left(R_{0}, R_{1}\right.$ and $\left.R_{2}\right)$ containing 0,1 and $2 \%$ dried leaves of Chromolaena odorata respectively were tested. Studied microorganisms isolated were total coliforms, Escherichia coli, Salmonella sp., klebsiella sp., yeasts and molds. Bacterial load varied from $10 \times 10^{4}$ to $5236 \times 10^{4}$ $\mathrm{CFU} / \mathrm{g}$ for $\mathrm{R}_{0}$, from $64 \times 10^{4}$ to $12317 \times 10^{4} \mathrm{CFU} / \mathrm{g}$ for $\mathrm{R}_{1}$ and from $1 \times 10^{4}$ to $4292 \times 10^{4}$ $\mathrm{CFU} / \mathrm{g}$ for $\mathrm{R}_{2}$ Whereas fungal load fluctuated between $34 \times 10^{4}$ and $3786 \times 10^{4} \mathrm{CFU} / \mathrm{g}$ for $\mathrm{R}_{0}$, between $153 \times 10^{4}$ and $8988 \times 10^{4} \mathrm{CFU} / \mathrm{g}$ for $\mathrm{R}_{1}$ and between $8 \times 10^{4}$ and 18154 $\mathrm{x} 10^{4} \mathrm{CFU} / \mathrm{g}$ for $\mathrm{R}_{2}$. This flora was subject to wide temporal fluctuations. The analysis of these results considered the interaction of the different variables (gender, weight and time). Apart from the time factor (weeks) which significantly $(p<0.05)$ influenced the abundance of Escherichia coli, yeast and mold, no other factor had a significant effect on the evolution of the cloacal microflora of these birds. However, linear relationships between the factors ration, gender, time and weight evolution of microbial cells revealed a significant effect $(p<0.05)$. This action resulted in an improvement of the feed conversion ratio and an increase in live weight of the studied birds which was most marked for the $\mathrm{R}_{1}$ ration and in males.

\section{Introduction}

Sustainable production of poultry meat and eggs is important to provide safe and quality protein sources in human diets worldwide
(Kogut and Oakley, 2016). The gastrointestinal tract (GIT) of chickens contains a diverse and complex flora that plays an essential role in digestion and nutrient absorption, immune system 
development and pathogen exclusion (Shang et al., 2018). The digestive flora includes single-celled organisms namely bacteria, fungi and protozoa. Regarding bacterial populations, which are the predominant microorganisms, they represent a wide range of metabolic and morphological types. Their total number is greater than the number of eukaryotic cells constituting the host body. A distinction is made between dominant $\left(>10^{6}\right.$ Colony Forming Units (CFU)/g content), subdominant $\left(10^{5}-10^{3} \mathrm{CFU} / \mathrm{g}\right.$ content $)$, and residual $\left(<10^{3}\right.$ CFU/g content) bacteria (Oakley et al., 2014; Pan and $\mathrm{Yu}, 2014)$. In chickens, the main sites of bacterial activity are the crop, caeca and, to a lesser extent, the small intestine.

In the crop, facultative anaerobic bacteria (lactobacilli, streptococci and coliforms) are mainly found, but also yeast. In the caeca, strict anaerobes such as Eubacterium, Bifidobacteria or Clostridia are in the majority, but facultative anaerobic bacteria are also present. Thus, in caeca, $10^{11}$ and $10^{9}$ bacteria are found per $\mathrm{g}$ of content respectively (Gabriel et al., 2005). The composition and function of these communities vary according to bird age, gender and diet (Shang et al., 2018).

Several studies have been carried out comparing animals fed with and without antibiotics and the influence of these chemicals on the floral walls of animals (Djellout et al., 2018). With the abolition of Growth Promoting Antibiotics (GPAs), research is now focusing on the microflora of farmed animals, including poultry, and the changes it may undergo (Afssa, 2007). Plantbased products, already used for their effects on zootechnical performance in poultry since the 1990s, have thus seen their use increase significantly (Brenes and Roura, 2010).

Chromolaena odorata (L.) R. M. King and Robinson belongs to the family Asteraceae
(Ngono Ngane et al.,2006; IUCN/PACO, 2013). In traditional medicine, it has been cited for several uses. It has anti-parasitic and insecticidal, antioxidant, anti-diabetic, immunostimulant, antibacterial, antiinflammatory, antiviral, anti-allergic and antifungal properties (Bouda et al., 2001; Pamo et al., 2004; Ngono Ngane et al., 2006; Mbajiuka et al., 2014; Adedapo et al., 2016). In poultry nutrition, an inclusion level of up to $5 \%$ of $C$. odorata leaves seems to support a desirable health status in haematological and biochemical reports (Fasuyi et al., 2005).

These authors also noted that egg production and feed intake increased at up to $5 \%$ inclusion of $C$. odorata powder, an a slight decrease beyond that threshold. It is in this context that this work whose aim was to evaluate the evolution of cloacal bacteria and fungi in Brahma chickens (Gallus gallus domesticus) fed with a $C$. odorata supplement was carried out. The hypothesis was that addition of $C$. odorata to the birds' diet would favor the development of cloacal microorganisms.

\section{Materials and Methods}

\section{Plant material}

The plant material for this study was dried leaves of Chromolaena odorata (L.) R. M. King and Robinson (Asteraceae). Fresh leaves were collected during the period of April-May 2019 corresponding to the rainy season (when biomass is abundant), in the campus of the Institute of Agricultural Research for Development (IRAD) Nkolbisson located in Yaoundé, Cameroon (Central Africa). The choice of this plant as function of its different uses, its availability, its invasiveness and the ethno-medicinal information obtained from traditional healers in certain localities. The identification of this plant was carried out at the National Herbarium (IRAD). 


\section{Preparation of Chromolaena odorata powder}

The powder was obtained according to the method used in traditional method (Adedapo et al., 2016). The harvested leaves were weighed, washed, drained and dried in the laboratory at room temperature $\left(22 \pm 2^{\circ} \mathrm{C}\right)$ to avoid any degradation of the active ingredients. During drying, the leaves were regularly aerated to avoid contamination by fungi. Once dried, the leaves were ground using an electric grinder (brand of blender) and the resulting powder was stored in plastic bags at room temperature, in a dry place and protected from humidity and light until further use.

\section{Animal material and experimental set-up}

In this study, forty-five parent stocks (Gallus gallus domesticus) aged 4-5 months with mean weights of $1 \mathrm{~kg}$ for females and $1.5 \mathrm{~kg}$ for males were randomly divided into 3 groups of 15 chickens. Each group was then subdivided into 3 replicates of 5 chickens each $(1$ male and 4 females) for a total of 9 experimental units. They were reared on deep litter at a density of 5 chickens $/ \mathrm{m}^{2}$. At this stage, a control ration $\left(\mathrm{R}_{0}\right)$ was made (Table 1$)$ and 2 other rations containing $1 \%\left(\mathrm{R}_{1}\right)$ and $2 \%\left(\mathrm{R}_{2}\right)$ of $C$. odorata powder. Each of the 3 experimental rations was randomly allocated to the experimental units in a completely randomized design. The chemical composition of the proposed rations in the different groups is presented in Table 1. The animals were fed according a ration plan and water given $a d$ libitum. The study lasted 10 weeks $\left(\mathrm{W}_{1}\right.$ to $\mathrm{W}_{10}$ ) and sampling and weighing of birds were carried out every week.

\section{Cloacal sampling and microbiological analysis}

In each experimental unit, feces were collected from one male and one female directly from the cloaca of each bird, using sterile swabs.

A total of 9 samples were taken on each visit. Each sample was weighed and then introduced into a $2.5-5 \mathrm{ml}$ of sterile physiological water depending on the consistency.

The suspension was then homogenized using a grinder to obtain a $1 / 10$ stock suspension. A series of dilutions down to $10^{-5}$ was made from the stock solution by taking $1 \mathrm{ml}$ each time to add to $9 \mathrm{ml}$ of distilled water contained in a test tube. $100 \mu$ l of the final sample was taken with a micropipette and spread on cast agar in Petri dishes around the sterility diameter of the Bunsen burner flame (Rodier et al., 2016).

The main selective media used for isolation and enumeration of microbiological colonies are described in Table 2. The reading of germs (colonies) on the colony counter for the enumeration of considerable colonies was performed according to the ISO-AFNOR standard (NF V08-010 1986).

All colonies present in the solid culture media were identified according to standard biochemical criteria (Holt et al., 2000). The results were expressed as $\mathrm{CFU} / \mathrm{g}$ (colony forming units per gram).

\section{Statistical analyses}

Statistical analyses of the data were carried out using the International Business Machine Statistical Package of Social Science version 20 ((SPSS 20). All histograms were generated using Microsoft Excel 2010. Relationships between cell abundances were assessed by Pearson correlation tests. Comparisons of the means of cell abundances of the data by ration, time and gender were performed using the analysis of variance (ANOVA) test. The significance level considered was $5 \%$. 


\section{Results and Discussion}

\section{Variation in microbial abundance in males}

Total coliform (TC) concentration in males were fed with $\mathrm{R}_{0}$ control ration that ranged from $0 \times 10^{4}$ to $10696 \times 10^{4} \mathrm{CFU} / \mathrm{g}, 10587 \times 10^{4}$ to $11 \times 10^{4} \mathrm{CFU} / \mathrm{g}$ for the $1 \% \mathrm{C}$. odorata powder ration $\left(\mathrm{R}_{1}\right), 33589 \times 10^{4}$ to $11 \times 10^{4}$ $\mathrm{CFU} / \mathrm{g}$ for the $2 \% \mathrm{C}$. odorata powder ration $\left(\mathrm{R}_{2}\right)$ (Figure 1A). Maximum concentrations were recorded at $\mathrm{W}_{9}$ and $\mathrm{W}_{3}$ for $\mathrm{R}_{0}$ and $\mathrm{R}_{1}$ respectively and at $W_{2}$ for $R_{2}$. The mean bacterial abundances of the three rations were $2035 \times 10^{4}, 2465 \times 10^{4}$ and $5830 \times 10^{4} \mathrm{CFU} / \mathrm{g}$ respectively.

The concentration of $E$. coli fluctuated from $0 \times 10^{4}$ to $5323 \times 10^{4} \mathrm{CFU} / \mathrm{g}$ for $\mathrm{R}_{0}$ at $\mathrm{W}_{6}$ and $\mathrm{W}_{9}$ respectively, $0 \times 10^{4}$ to $3327 \times 10^{4} \mathrm{CFU} / \mathrm{g}$ for $\mathrm{R}_{1}$ at $\mathrm{W}_{2}$ and $\mathrm{W}_{9}$ respectively, $14319 \times 10^{4}$ to $2 \times 104 \mathrm{CFU} / \mathrm{g}$ for $\mathrm{R}_{2}$ at $\mathrm{W}_{8}$ and $\mathrm{W}_{2}$ respectively (Figure 1B). The mean values of the three rations were $1071 \times 10^{4}, 520 \times 10^{4}$ and $1985 \times 10^{4} \mathrm{CFU} / \mathrm{g}$ respectively.

Klebsiella $s p$. counts ranged from $0 \times 10^{4}$ to $4041 \times 10^{4} \mathrm{CFU} / \mathrm{g}$ for $\mathrm{R}_{0}$ at $\mathrm{W}_{6}$ and $\mathrm{W}_{9}$ respectively, $0 \times 10^{4}$ to $1599 \times 10^{4} \mathrm{CFU} / \mathrm{g}$ for $\mathrm{R}_{1}$ at $\mathrm{W}_{3}$ and $\mathrm{W}_{9}$ respectively and $0 \times 10^{4}$ to $28822 \times 10^{4} \mathrm{CFU} / \mathrm{g}$ for $\mathrm{R}_{2}$ at $\mathrm{W}_{1}$ and $\mathrm{W}_{4}$ respectively (Figure 1C). The means of the three rations were $672 \times 10^{4}, 368 \times 10^{4}$ and $3978 \times 10^{4} \mathrm{CFU} / \mathrm{g}$ respectively.

For Salmonella sp. concentrations ranged from $167 \times 10^{4}$ to $0 \times 10^{4} \mathrm{CFU} / \mathrm{g}$ for $\mathrm{R}_{0}$ and $0.05 \times 10^{4}$ to $0 \times 10^{4} \mathrm{CFU} / \mathrm{g}$ for $\mathrm{R}_{1}$. Maximum concentrations were recorded at $\mathrm{W}_{5}$ and $\mathrm{W}_{1}$ for $\mathrm{R}_{0}$ and $\mathrm{R}_{1}$ respectively. The $\mathrm{R}_{2}$ treatment was free of Salmonella (Figure 1D).

Yeast concentration ranged from $1475 \times 10^{4}$ to 0x $10^{4} \mathrm{CFU} / \mathrm{g}$ for $\mathrm{R}_{0}, 0 \times 10^{4}$ to $252 \times 10^{4} \mathrm{CFU} / \mathrm{g}$ for $\mathrm{R}_{1}$, and $16202 \times 10^{4}$ to $0 \times 10^{4} \mathrm{CFU} / \mathrm{g}$ for $\mathrm{R}_{2}$. The mean values of the three rations were
$234 \times 10^{4}, \quad 64 \times 10^{4}$ and $2643 \times 10^{4} \quad \mathrm{CFU} / \mathrm{g}$ respectively. Maximum concentrations were recorded in weeks $\mathrm{W}_{2}, \mathrm{~W}_{7}$, and $\mathrm{W}_{4}$ for $\mathrm{R}_{0}, \mathrm{R}_{1}$ and $\mathrm{R}_{2}$ respectively (Figure $1 \mathrm{E}$ ).

Mold concentration fluctuated from $0 \times 10^{4}$ to $96 \times 10^{4} \mathrm{CFU} / \mathrm{g}$ for $\mathrm{R}_{0}, 0 \times 10^{4}$ to $40 \times 10^{4} \mathrm{CFU} / \mathrm{g}$ for $\mathrm{R}_{1}$ and $0 \times 10^{4}$ to $55 \times 10^{4} \mathrm{CFU} / \mathrm{g}$ for $\mathrm{R}_{2}$ (Figure 1F). The mean values of the three rations were $15 \times 10^{4}, 11 \times 10^{4}$ and $12 \times 10^{4}$ $\mathrm{CFU} / \mathrm{g}$ respectively.

\section{Variation in microbial abundance in females}

The total coliform concentration varied from $6 \times 10^{4}$ to $11754 \times 10^{4} \mathrm{CFU} / \mathrm{g}$ for ration $\mathrm{R}_{0}$ at weeks $\mathrm{W}_{8}$ and $\mathrm{W}_{9}$ respectively, $229 \times 10^{4}$ to $200000 \times 10^{4} \mathrm{CFU} / \mathrm{g}$ for $\mathrm{R}_{1}$ at $\mathrm{W}_{1}$ and $\mathrm{W}_{2}$ respectively, $11574 \times 10^{4}$ to $178 \times 10^{4} \mathrm{CFU} / \mathrm{g}$ for $\mathrm{R}_{2}$ at $\mathrm{W}_{3}$ and $\mathrm{W}_{10}$ respectively (Figure $2 \mathrm{~A}$ ). The mean of the three rations were $2109 \times 10^{4}$, $22169 \times 10^{4}$ and $2846 \times 10^{4} \mathrm{CFU} / \mathrm{g}$ respectively.

The concentration of $E$. coli fluctuated from $0 \times 10^{4}$ to $6513 \times 10^{4} \mathrm{CFU} / \mathrm{g}$ for $\mathrm{R}_{0}$ at $\mathrm{W}_{6}$ and $\mathrm{W}_{9}$ respectively, $0 \times 10^{4}$ to $20200 \times 10^{4} \mathrm{CFU} / \mathrm{g}$ for $\mathrm{R}_{1}$ at $\mathrm{W}_{1}$ and $\mathrm{W}_{2}$ respectively, $0 \times 10^{4}$ to $2293 \times 10^{4} \mathrm{CFU} / \mathrm{g}$ for $\mathrm{R}_{2}$ at $\mathrm{W}_{3}$ and $\mathrm{W}_{7}$ respectively (Figure 2B). The means of the three rations were $838 \times 10^{4}, 2758 \times 10^{4}$ and $625 \times 10^{4} \mathrm{CFU} / \mathrm{g}$ respectively.

Klebsiella $s p$. counts showed concentrations ranging from $90063 \times 10^{4}$ to $0 \times 10^{4} \mathrm{CFU} / \mathrm{g}$ for $\mathrm{R}_{0}$ at $\mathrm{W}_{2}$ and $\mathrm{W}_{6}$ respectively, $51494 \times 10^{4}$ to $6 \times 10^{4} \mathrm{CFU} / \mathrm{g}$ for $\mathrm{R}_{1}$ at $\mathrm{W}_{2}$ and $\mathrm{W}_{8}$ respectively and $21840 \times 10^{4}$ to $2 \times 10^{4} \mathrm{CFU} / \mathrm{g}$ for $\mathrm{R}_{2}$ at $\mathrm{W}_{3}$ and $\mathrm{W}_{10}$ respectively (Figure $2 \mathrm{C}$ ). The mean of the three rations were $9801 \times 10^{4}$, $9158 \times 10^{4}$ and $3000 \times 10^{4} \mathrm{CFU} / \mathrm{g}$ respectively. For Salmonella sp. concentrations ranged from $9 \times 10^{4}$ to $0 \times 10^{4} \mathrm{CFU} / \mathrm{g}$ for $\mathrm{R}_{0}$ and $1067 \times 10^{4}$ to 0x $10^{4} \mathrm{CFU} / \mathrm{g}$ for $\mathrm{R}_{1}$. Maximum concentrations were recorded at $W_{1}$ for both rations. The $R_{2}$ ration was free of Salmonella throughout the study (Figure 2D). 
Table.1 Composition of experimental ration

\begin{tabular}{|c|c|c|c|}
\hline & \multicolumn{3}{|c|}{ Rations } \\
\hline Ingredients (kg) & $\mathbf{R}_{\mathbf{0}}$ & $\mathbf{R}_{\mathbf{1}}$ & $\mathbf{R}_{\mathbf{2}}$ \\
\hline Maize & 51.8 & 51.8 & 51.8 \\
\hline Wheat Bran & 7 & 7 & 7 \\
\hline Soya meal & 15 & 15 & 75 \\
\hline Cotton seed cake & 7 & 7 & 5 \\
\hline Fish meal & 5 & 5 & 8 \\
\hline oyster shell & 8 & 8 & 5 \\
\hline Concentrate 5\% & 5 & 5 & 2 \\
\hline Bone meal & 2 & 2 & 0.1 \\
\hline Elitox & 0.1 & 0.1 & 2 \\
\hline Bicalphos & 0.1 & 1 & 102 \\
\hline Chromonla Odorata & 0 & 101 & 2726.5 \\
\hline Powder & 100 & 2700 & 21.15 \\
\hline Total & Calculated chemical Composition & 4.13 \\
\hline ME(Kcal/Kg) & 2673 & 21.48 & 4.39 \\
\hline Crude Protein \% & 21.49 & 4.12 & 0.77 \\
\hline Fat & 4.11 & 4.33 & 1.12 \\
\hline Calcium \% & 4.37 & 0.78 & 0.47 \\
\hline Phosphorus \% & 0.78 & 1.13 & 0.47 \\
\hline Total Lysine\% & 1.13 & 0.13 & \\
\hline Total Methionine & 0.47 & & \\
\hline
\end{tabular}

$R_{0}=0 \%$ de la poudre de C. odorata, $R_{I}=1 \%$ de la poudre de C. odorata, $R_{2}=2 \%$ de la poudre de C. odorata, ME : metabolic energy

Table.2 Main selective media used for colony isolation and enumeration

\begin{tabular}{|c|c|c|c|}
\hline Germs & Agar & Temperature & Incubation time \\
\hline Total coliforms (TC) & Endo agar & $37^{\circ} \mathrm{C}$ & 18 to $24 \mathrm{~h}$ \\
\hline $\begin{array}{c}\text { Eschericia coli }(\boldsymbol{E} . \\
\text { coli) }\end{array}$ & EMB agar & $44^{\circ} \mathrm{C}$ & 48 to $72 \mathrm{~h}$ \\
\hline Salmonella sp. & $\begin{array}{c}\text { Salmonella-Shigella } \\
\text { agar (SS) }\end{array}$ & $37^{\circ} \mathrm{C}$ & 18 to $24 \mathrm{~h}$ \\
\hline klebsiella sp. & $\begin{array}{c}\text { Levine EMB Blue } \\
\text { Agar (EMB) }\end{array}$ & $37^{\circ} \mathrm{C}$ & 18 to $24 \mathrm{~h}$ \\
\hline Yeasts and molds & $\begin{array}{c}\text { Potatoes dextrose } \\
\text { agar (PDA) } \\
\text { chloramphenicol }\end{array}$ & $22^{\circ} \mathrm{C}$ & 48 to $72 \mathrm{~h}$ \\
\hline
\end{tabular}


Table.3 Correlation matrix (Pearson) between cell abundances

\begin{tabular}{|c|c|c|c|c|c|c|}
\hline & $\begin{array}{c}\text { E. coli } \\
\text { (UFC/g) }\end{array}$ & $\begin{array}{c}\text { Total } \\
\text { coliforms } \\
\text { (UFC/g) }\end{array}$ & $\begin{array}{c}\text { Salmonella } \\
\text { sp. (UFC/g) }\end{array}$ & $\begin{array}{c}\text { Klebsiella } \\
\text { sp. (UFC/g) }\end{array}$ & $\begin{array}{c}\text { Yeasts } \\
\text { (UFC/g) }\end{array}$ & $\begin{array}{c}\text { Molds } \\
\text { (UFC/g) }\end{array}$ \\
\hline $\begin{array}{c}\text { E.coli } \\
\text { (UFC/g) }\end{array}$ & 1 & & & & & \\
\hline $\begin{array}{c}\text { Total } \\
\text { coliforms } \\
\text { (UFC/g) }\end{array}$ & $\mathbf{0 . 6 5 4 * *}$ & 1 & & & \\
\hline $\begin{array}{c}\text { Salmonella } \\
\text { sp. (UFC/g) }\end{array}$ & $\mathbf{0 . 5 3 4 * *}$ & $\mathbf{0 . 9 5 8 * *}$ & 1 & & & \\
\hline $\begin{array}{c}\text { Klebsiella sp. } \\
\text { (UFC/g) }\end{array}$ & $\mathbf{0 . 1 8 6 *}$ & 0.072 & -0.008 & 1 & & \\
\hline $\begin{array}{c}\text { Yeasts } \\
\text { (UFC/g) }\end{array}$ & $\mathbf{0 . 2 4 4 * *}$ & $\mathbf{0 . 2 7 7 * *}$ & $\mathbf{0 . 2 5 2 * *}$ & $\mathbf{0 . 2 8 8 * *}$ & 1 & \\
\hline $\begin{array}{c}\text { Molds } \\
\text { (UFC/g) }\end{array}$ & $\mathbf{0 . 6 1 1 * *}$ & $\mathbf{0 . 5 7 4 * *}$ & $\mathbf{0 . 4 9 0 * *}$ & $\mathbf{0 . 3 6 0 * *}$ & $\mathbf{0 . 2 9 8 * *}$ & 1 \\
\hline
\end{tabular}

*correlation significant at $0.05, * *$ correlation significant at 0.01

Table.4 Analysis of variance and regression (ANOVA)

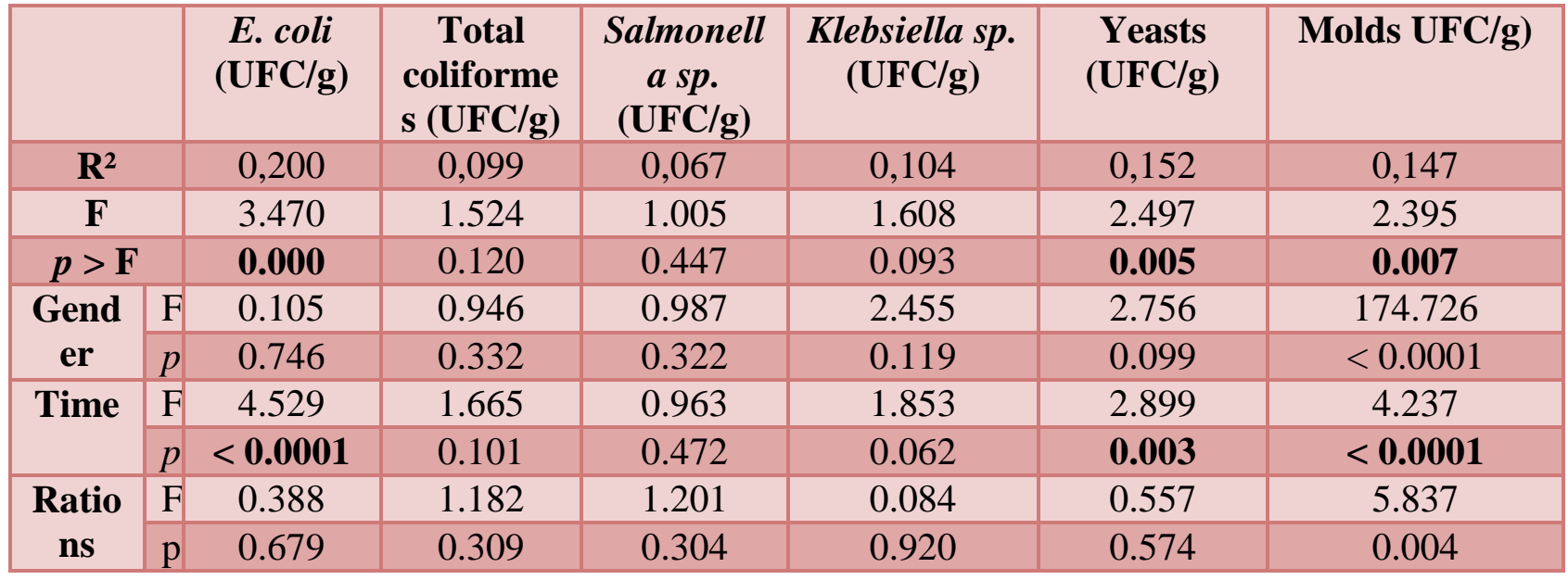


Fig.1 Variation in total coliforms (A), E. coli (B), Klebsiella sp. (C), Salmonella sp. (D), yeasts (E) and molds (F) in males fed $\mathrm{R}_{0}, \mathrm{R}_{1}$ and $\mathrm{R}_{2}$ rations.
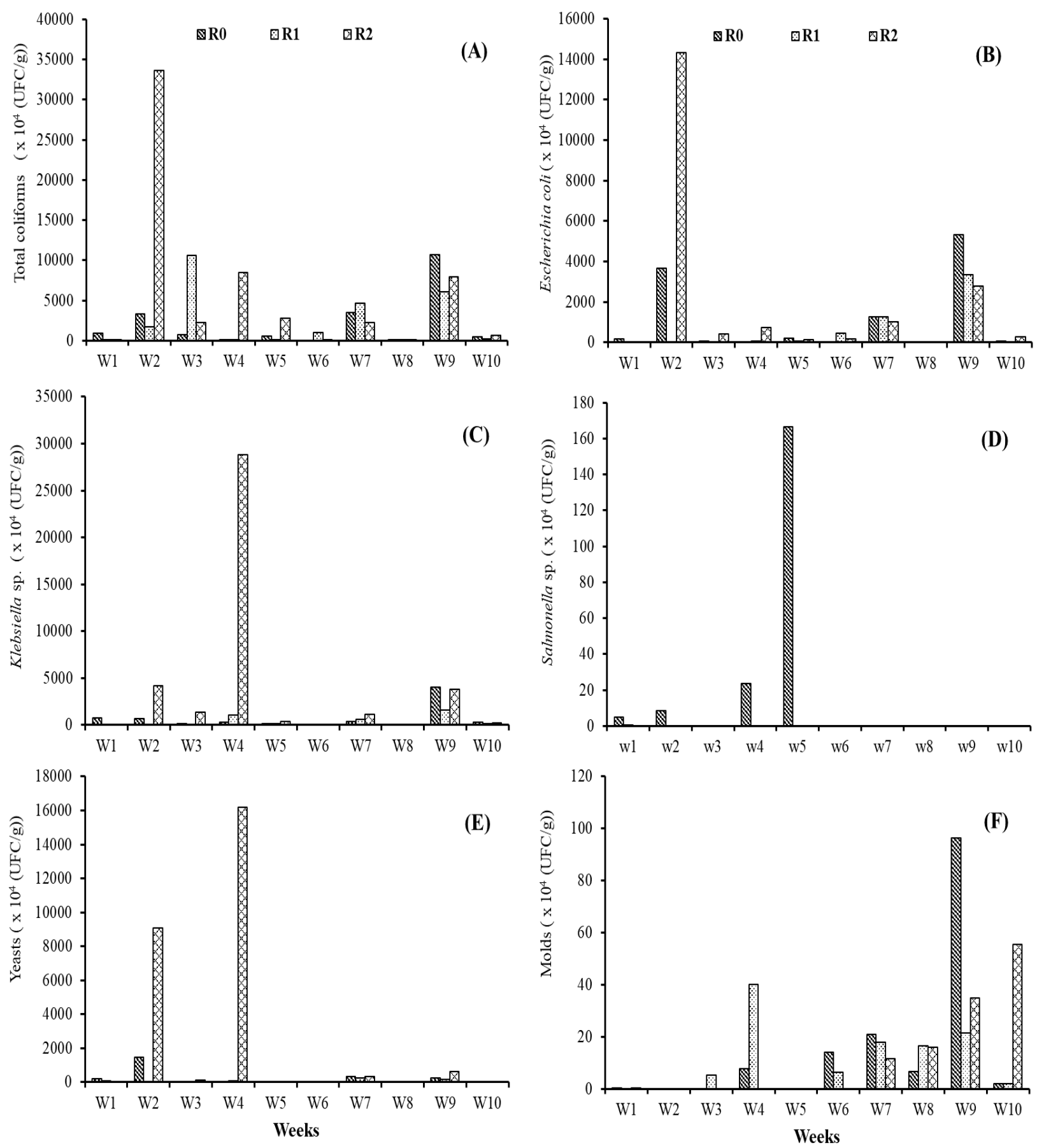
Fig.2 Variation in total coliforms (A), E. coli (B), Klebsiella sp. (C), Salmonella sp. (D), yeasts (E) and molds (F) in females fed $\mathrm{R}_{0}, \mathrm{R}_{1}$ and $\mathrm{R}_{2}$.
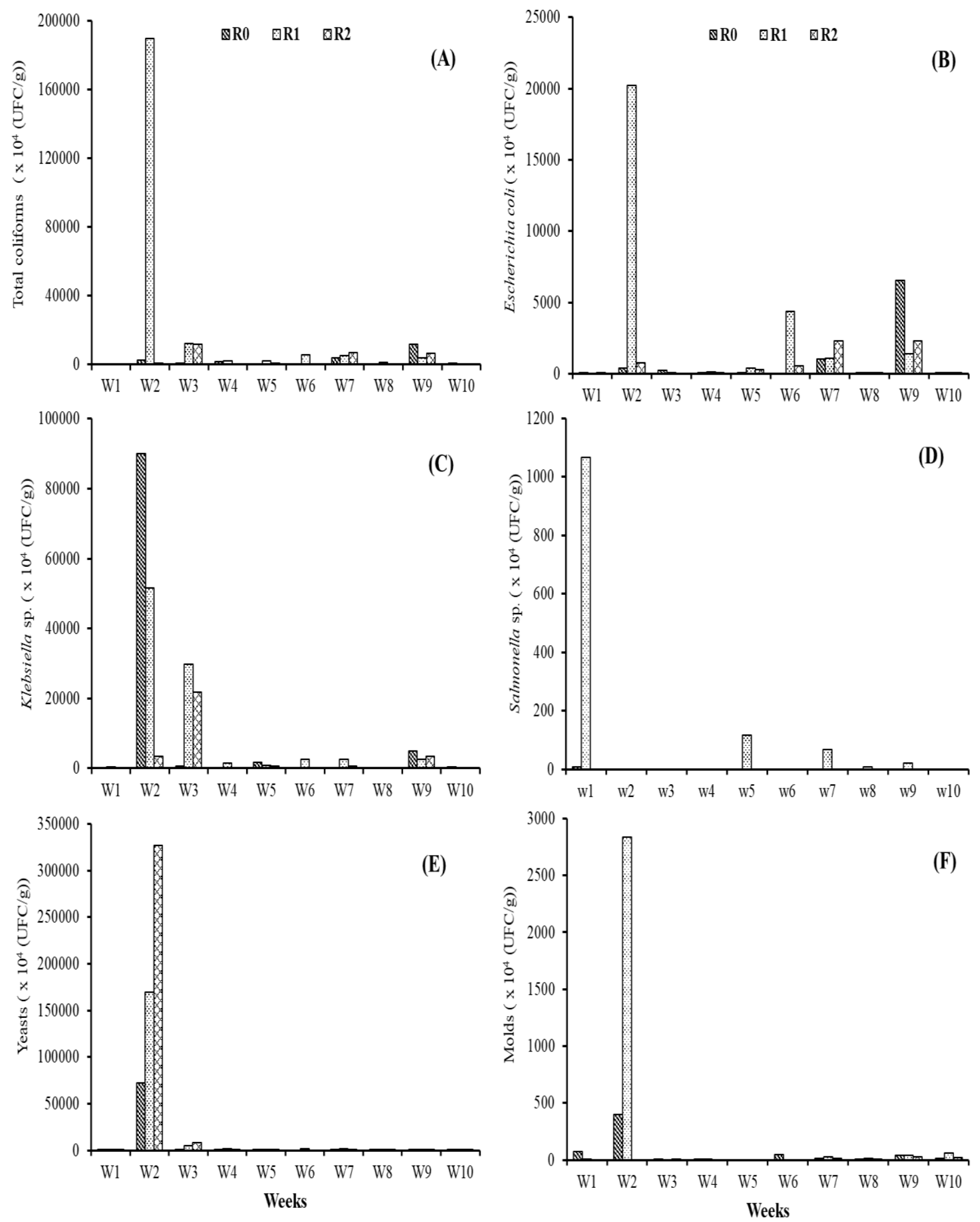
Table.5 Live weight $(\mathrm{Kg})$ of chickens according to ration, gender and time

\begin{tabular}{|c|c|}
\hline Sources of variation & Weight $(\mathbf{K g})$ \\
\hline Rations & $* *$ \\
\hline $\mathbf{R}_{\mathbf{0}}$ & $2.072 \pm 0.028 \mathrm{~b}$ \\
\hline $\mathbf{R}_{\mathbf{1}}$ & $2.197 \pm 0.028 \mathrm{a}$ \\
\hline Render & $2.094 \pm 0.028 \mathrm{~b}$ \\
\hline Male & $* * *$ \\
\hline Female & $2.332 \pm 0.023 \mathrm{a}$ \\
\hline Time & $1.910 \pm 0.023 \mathrm{~b}$ \\
\hline Week 1 & $* * *$ \\
\hline Week 2 & $2.048 \pm 0.051 \mathrm{bc}$ \\
\hline Week 3 & $2.096 \pm 0.051 \mathrm{bc}$ \\
\hline Week 4 & $2.013 \pm 0.051 \mathrm{c}$ \\
\hline Week 5 & $2.094 \pm 0.051 \mathrm{bc}$ \\
\hline Week 6 & $2.094 \pm 0.051 \mathrm{bc}$ \\
\hline Week 7 & $2.097 \pm 0.051 \mathrm{bc}$ \\
\hline Week 8 & $2.084 \pm 0.051 \mathrm{bc}$ \\
\hline Week 9 & $2.207 \pm 0.051 \mathrm{~b}$ \\
\hline Week 10 & $2.382 \pm 0.051 \mathrm{a}$ \\
\hline \multirow{4}{*}{ (a) $p<0.01, * * * 096 \pm 0.051 \mathrm{bc}$} \\
\hline
\end{tabular}

Fig.3 Concentration of microbial populations as a function of ration (A), gender (B) and time (weeks) (C)
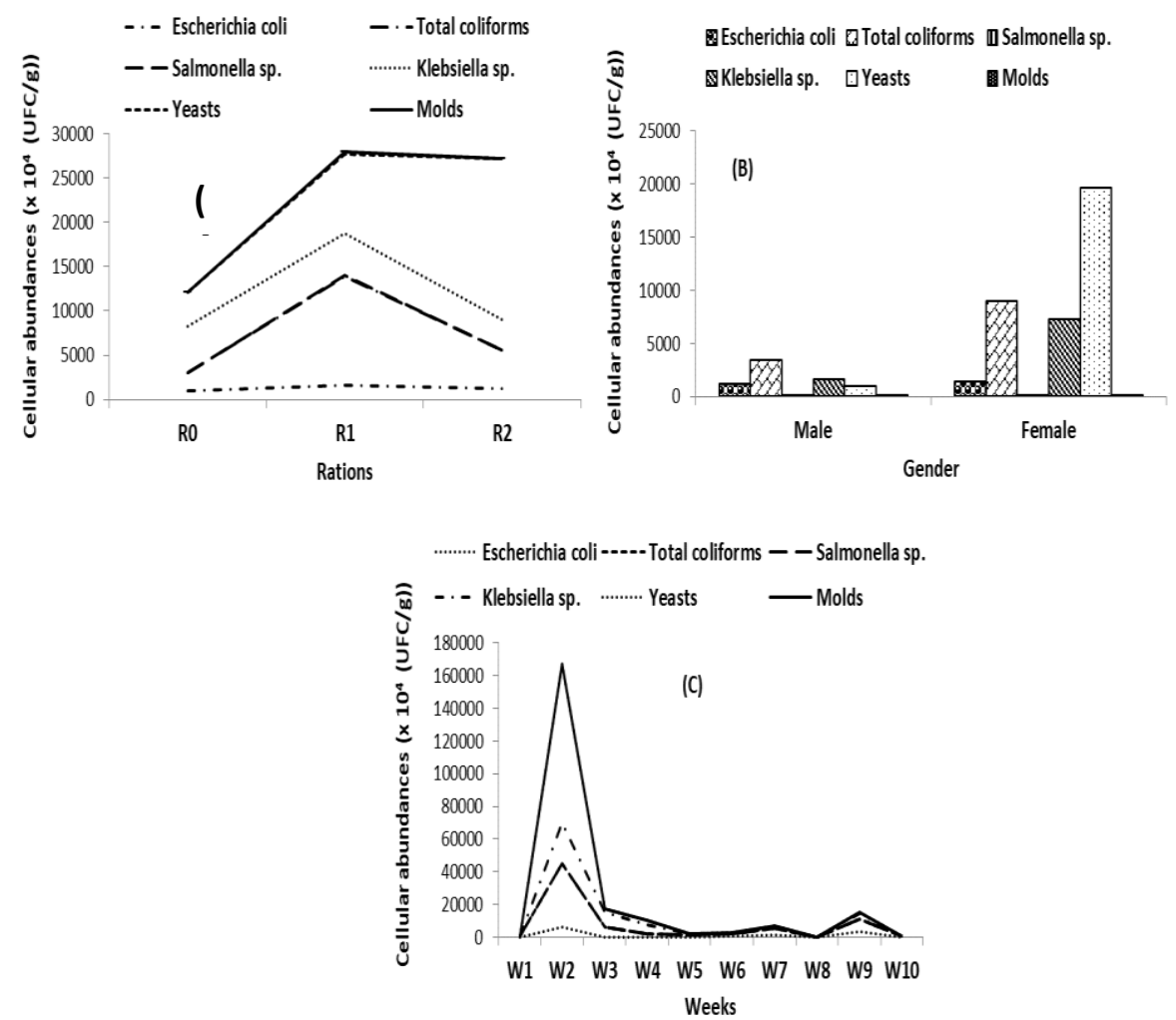
Yeast concentrations ranged from $72467 \times 10^{4}$ to $0 \times 10^{4} \mathrm{CFU} / \mathrm{g}$ for $\mathrm{R}_{0}$, from $200000 \times 10^{4}$ to $8 \times 10^{4} \mathrm{CFU} / \mathrm{g}$ for $\mathrm{R}_{1}$, and $300000 \times 10^{4}$ to $0 \times 10^{4}$ $\mathrm{CFU} / \mathrm{g}$ for $\mathrm{R}_{2}$. The mean of the three rations were $7396 \times 10^{4}, 18006 \times 10^{4}$ and $33666 \times 10^{4}$ $\mathrm{CFU} / \mathrm{g}$ respectively. Maximum concentrations were recorded at $\mathrm{W}_{2}$ for all three rations and minimum concentrations at $\mathrm{W}_{6}, \mathrm{~W}_{10}$ and $\mathrm{W}_{6}$ for $R_{0}, R_{1}$ and $R_{2}$ respectively (Figure $2 E$ ).

Molds concentrations fluctuated from $400 \times 10^{4}$ to $0 \times 10^{4} \mathrm{CFU} / \mathrm{g}$ for $\mathrm{R}_{0}, 2833 \times 10^{4}$ to $0 \times 10^{4}$ CFU/g for $\mathrm{R}_{1}$ and $31 \times 10^{4}$ to $0 \times 10^{4} \mathrm{CFU} / \mathrm{g}$ for $\mathrm{R}_{2}$ (Figure $2 \mathrm{~F}$ ). The means of the three rations were $61 \times 10^{4}, 300 \times 10^{4}$ and $8 \times 10^{4} \mathrm{CFU} / \mathrm{g}$ respectively.

\section{Correlation between the parameters studied}

Pearson's correlation test for the data from the 180 samples indicated a degree of association between cell abundances $(p<0.01)$ throughout the study (Table 3).

The analysis of variance and regression (Table 4) shows that $20 \% ; 9.9 \% ; 6.7 \% ; 10.4 ; 15.2 \%$ and $14.7 \%$ of the variability observed in $E$. coli, total coliforms, Salmonella sp., Klebsiella sp., yeasts and molds, respectively, is explained by ration, time and gender. The rest of the variability was explained by effects that were not identified during the study. The contribution to the total variability observed within these different bacteria was statistically significant $(p<0.05)$ in E. coli, yeasts and molds.

Apart from the time factor (weeks) which significantly $(p<0.05)$ influenced E. coli, yeasts and molds, no other factor had a significant effect on the evolution of the microbiological flora of chicken feces. However, the linear relationships between the factors (ration, gender and time) and weight evolution reveal a significant effect $(p<0.05)$. Indeed, there is evidence of an increase in microbial flora for all three rations with higher abundances at ration $\mathrm{R}_{1}$ (Figure $3 \mathrm{~A}$ ). On the other hand, higher abundances were observed in females (Figure 3B), and decrease with time (Figure 3C).

The average weight according to ration, gender and time is summarized in Table 5. This action results in an increase in live weight of the animals, which was more pronounced for the $\mathrm{R}_{1}$ ration and in males.

The cloacal harbours a very diverse, rich and stable microbial community (Videnska et al., 2013; Juan et al., 2019). The microbial flora of the cloaca analyzed was subject to temporal fluctuations. It varied from $10^{4}$ to $10^{7} \mathrm{CFU} / \mathrm{g}$ for the $\mathrm{R}_{0}$ control ration, from $10^{5}$ to $10^{8}$ $\mathrm{CFU} / \mathrm{g}$ for the $1 \% \mathrm{C}$. odorata powder ration $\left(\mathrm{R}_{1}\right)$ and from $10^{4}$ to $10^{8} \mathrm{CFU} / \mathrm{g}$ for the $2 \% C$. odorata powder ration $\left(\mathrm{R}_{2}\right)$. According to Gabriel et al., (2005), in this region, microbial concentrations vary between $10^{9}$ and $10^{11}$ $\mathrm{CFU}$ per $\mathrm{g}$ of content. The fluctuations observed would be linked to the ration administered. Indeed, the concentrations of total coliforms, E. coli and klebsiella sp. increased throughout the study and this increase was more pronounced in subjects fed $1 \%$ C. odorata powder ration $\left(\mathrm{R}_{1}\right)$ supplemented diets. Feeding approaches were monitored to clarify the impact of feed intake on caeca, physiological and functional characteristics in broilers with different residual feed as a measure of feed efficiency (Stanley et al., 2016; Metzler-Zebeli et al., 2019). They described that predominant families such as Enterobacteriaceae was more affected by the diet. The composition and function of these communities have been shown to vary with dietary components (Pan and Yu, 2014; Oakley BB, 2014; Kogut MH and Oakley BB, 2016). The digestive flora is directly dependent on the diet since the diet determines the type of substrate available for the growth of microorganisms. 
Microbial flora analysis of cloaca differed according to the sex of the animals: higher populations were observed in females. Indeed, everyone has its own microbial community (Zhu et al., 2002) and implies that hostspecific factors are involved in the establishment of the gut flora.

As with regards to the relation between fed supplementation, growth and evolution of microbial flora, birds fed with diets supplanted at $\mathrm{R}_{1}$ had the highest live weight gain. This showed that addition of $1 \% C$. odorata to the chickens' diet had an impact on the digestive physiology of the subjects, increasing the digestibility of the feed by the microorganisms. The microorganisms compete with the host for use of feed in the digestive tract and are due to the fact that. They have a very large number of enzymes compared to their host, and those in the intestinal lumen can utilize certain food constituents. Feed that are not easily digestible by the host are the most affected. Thus, depending on the diet, the flora is involved in the digestion of food (Langhout et al., 2000), (Maisonnier et al., 2003). These microorganisms would have a positive effect by releasing nutrients that can be absorbed by the host in the cecum, which also have carbohydrate and amino acid transport capacities (Gabriel et al., 2005). Also, cloacal bacteria can convert uric acid into ammonia, which is then absorbed by the bird and used to produce amino acids such as glutamine (Vispo and Karasov, 1997).

In addition, some of the nitrogen from the diet is incorporated into the cellular proteins of the bacteria and therefore the bacteria themselves can be a source of protein/amino acids (Metges, 2000).

Furthermore, this flora may have a protective effect against harmful microorganisms and be partly responsible for the development of the bird's intestinal immune system. Overall, the presence of harmful flora negatively affects their growth. It can also affect the quality of animal products (meat, eggs). (Shang et al., 2018).

The addition of Chromolaena odorata to the birds' diet favored the growth cloacal microorganisms than the ration containing $1 \%$ Chromolaena odorata powder $\left(\mathrm{R}_{1}\right)$. This flora underwent fluctuations which would be related to the gender of the subjects and the incorporation time. The studied supplemented feeds affected not only the intestinal flora but also growth of birds and this was most pronounced at $R_{1}$ and in males.

\section{Acknowledgement}

The authors would like to thank the Institute of Agricultural Research for Development (IRAD) of Cameroon for funding with its Public Investment Budget and providing the necessary facilities for this work, as well as the Hydrobiology and Environment Laboratory of the University of Yaoundé 1 for providing their laboratory for bacterial and fungal analyses.

\section{References}

Adedapo, A. A., Ogunmiluyi, I. O., Adeoye, A. T., Ofuegbe, S. O., Emikpe, B. O. 2016. Evaluation of the medicinal potential of the methanol leaf extract of Chromolaena odorata in some laboratory animals. Journal of Medicinal Plants Studies, 4(3): 29-37.

AFSSA, 2007. Propositions pour une démarche d'évaluation de substances ou de produits «nouveaux» destinés à l'alimentation animale. Cas particulier des substances et produits à base de plantes. Rapport du groupe de travail AFSSA « Substances et produits nouveaux, ou à effet nouveau revendiqué, destinés à l'alimentation 
des animaux », Février 2007, 65p.

Bouda, H. et al., 2001. Effect of essential oils from leaves of Ageratum conyzoides, Lantana camara and Chromolaena odorata on the mortality of Sitophilus zeamais (Coleoptera, Curculionidae). Journal of Stored Products Research. 37(2): 103-109.

Brenes, A. and Roura, E. 2010. Essential oils in poultry nutrition: Main effects and modes of action. Anim. Feed Sci. Technol., 158: 1-14.

Djellout, B., Bouzagh, T., Dardabou, H., Benmohand, C., Aboun, A., Sahraoui, L., Zenia, S., Boudouma, D. and Ben Mahdi, M.H. 2018. Effet des huiles essentielles d'Origanum glandulosum et d'Origanum onites sur les performances zootechniques, la microflore digestive et les paramètres sanguins du poulet de chair. Livestock Research for Rural Development 30 (12).

Fasuyi, A. O., Fajemilehin, S. O. K. and Omojola, A. B. 2005. The egg quality characteristics of layers fed varying dietary inclusions of Siam weed (Chromolaena odorata) leaf meal (SWLM). International Journal of Poultry Science, 4 (10): 752 - 757.

Gabriel, S., Mallet, P. and Sibille, 2005. La microflore digestive des volailles : facteurs de variation et conséquences pour l'animal. INRA Prod. Anim., 18 (5): 309-322.

Holt, J. G., Krieg, N. R., Sneath, P. H. A., Staley, J. T. and Williams S. T. 2000. Bergey's Manual of determinative bacteriology. 9th edition. Lippincott Williams and Wilkins (Ed.), Philadelphia, 787p.

Juan, M., Diaz Carrasco, Natalia, A., Casanova and Mariano, Fernández Miyakawa, E. 2019. Microbiota, Gut Health and Chicken Productivity: What Is the Connection?
Microorganisms, 7, 374.

Kogut, M.H. and Oakley, B.B. 2016. Spatial and temporal changes in the broiler chicken caecal and fecal microbiomes and correlations of bacterial taxa with cytokine gene expression. Front Veter Sci. 3:11.

Langhout, D. J., Schutte, J. B., de Jong, J., Sloetjes, H., Verstegen, M. W. A. and Tamminga, S. 2000. Effect of viscosity on digestion of nutrients in conventional and germ-free chicks. $\mathrm{Br}$. J. Nut., 83, 533-540.

Maisonnier, S., Gomez, J., Bree, A., Berri, C., Baeza, E. and Carré B. 2003. Effects of microflora status, dietary bile salts and guar gum on lipid digestibility, intestinal bile salts and histomorphology, in broiler chickens. Poult. Sci., 82, 805814.

Mbajiuka, C. S., Obeagu, E. I., Chude, C. N. and Ibezie, O. E. 2014. Antimicrobial effects of Chromolaena odorata on some human pathogens. Int J Curr Microbiol Appl Sci, 3:1006-12.

Metges, C. C. 2000. Contribution of microbial amino acids to amino acid homeostasis of the host. J Nutrit., 130:1857S-64S.

Metzler-Zebeli, B. U., Siegerstetter, S.-C., Magowan, E., Lawlor, P. G., Petri, R. M., O'Connell, N. E. and Zebeli, Q. 2019. Feed restriction modifies intestinal microbiota-host mucosal networking in chickens divergent in residual feed intake. mSystems 4, e00261-18.

Ngono Ngane, A., Ebelle Etame, R., Ndifor, F., Biyiti, L., Amvam Zollo, P. H. and Bouchet, P. 2006. Antifungal activity of Chromolaena odorata (L.) King and Robinson (Asteraceae) of Cameroon. Chemotherapy, 52(2): 103-106.

Oakley, B. B., Lillehoj, H. S., Kogut, M. H., Kim, W. K., Maurer, J. J., Pedroso, A., et al., 2014. The chicken gastrointestinal microbiome. FEMS 
Microbiol Lett. 360:100-12.

Pamo, E., Tedonkeng, P. H., Amvam Zollo, F., Tendonkeng, J. R., Kana, M., Fongang, D. and Tapondjou, L. A. 2004. L'huile essentielle de $C$. odorata présente des effets insecticides majeurs sur Rhipicephalus lunulatus une tique de petits ruminants. Livestock Research for Rural Development, 16 (9).

Pan, D. and Yu, Z. 2014. Intestinal microbiome of poultry and its interaction with host and diet. Gut Microbes, 5:108-19.

Rodier, J., Legube, B. and Merlet, N. 2016. L'analyse de l'eau : Eaux naturelles, eaux résiduaires, eau de mer, Technique et ingénierie. Paris, Dunod, 10 éd, 1824p.

Shang, Y., Kumar, S., Oakley, B. and Kim, W. K. 2018. Chicken Gut Microbiota: Importance and Detection Technology. Front. Vet. Sci. 5:254.

Stanley, D., Hughes, R. J., Geier, M. S. and Moore, R. J. 2016. Bacteria within the gastrointestinal tract microbiota correlated with improved growth and feed conversion: Challenges presented for the identification of performance enhancing probiotic bacteria. Front. Microbiol. 7, 187.

UICN/PACO 2013. Plantes invasives affectant les aires protégées d'Afrique de l'Ouest : gestion pour la réduction des risques pour la biodiversité. UICN/PACO : Ouagadougou, Burkina Faso. 92p.

Videnska, P., Sisak, F., Havlickova, H., Faldynova, M., Rychlik, I. 2013. Influence of Salmonella enterica serovar enteritidis infection on the composition of chicken caeca microbiota. BMC Vet Res, 9:140.

Vispo, C. and Karasov, W. H. 1997. The interaction of avian gut microbes and their host: an elusive symbiosis. In: Gastrointestinal Microbiology Mackie R, White B, editors. New York, NY: Springer. p.116-55.

Zhu, X. Y., Zhong, T., Pandya, Y. and Joerger R. D. 2002. 16S rRNA-based analysis of microbiota from the caecum of broiler chickens. Appl. Environ. Microbiol., 68, 124-137.

\section{How to cite this article:}

Pierrette Ngo Bahebeck, Chouegouong Tuedom Mireille, Nguemmogue Ghislaine, Ghomsi Magne Sandra Olivia, Tamsa Arfao Antoine, Mama Iréne, Enamou Mbanga Gatien, Sulem Yong Nina Nindum and Etchu Kingsley Agbor. 2021. Evolution of Cloacal Bacteria and Fungi in Brahma Chickens (Gallus gallus domesticus) Fed with Chromolaena odorata Supplement. Int.J.Curr.Microbiol.App.Sci. 10(06): 484-496. doi: https://doi.org/10.20546/ijcmas.2021.1006.052 